\title{
Vaksinasjon mot helvetesild
}

\author{
Etter hvert som det blir stadig flere eldre i befolkningen, vil trolig antall tilfeller av herpes zoster og post- \\ herpetisk nevralgi øke. En vaksine mot herpes zoster er nylig blitt tilgjengelig i Norge. Sanofi Pasteur MSD \\ har mottatt en rekke spørsmål om vaksinen. Jeg ønsker med denne kommentaren å imøtekomme interessen.
}

Herpes zoster har en årlig insidens på ca. 8 per 1000 hos dem over 60 år $(1,2)$. Tilstanden skyldes reaktivering av varicella zoster-virus etter primærinfeksjon med varicella i barndommen. Aldersbetinget tap av spesifikk cellemediert immunitet er mulig årsak til reaktiveringen av virus $(3,4)$.

Den vanligste komplikasjonen er postherpetisk nevralgi, definert som dermatomal smerte som vedvarer 90 dager etter tilheling av det akutte utslettet (5). Insidensen øker med alderen - $\mathrm{i}$ én studie fra $8 \%$ i aldersgruppen 50-54 år til over $20 \%$ i aldersgruppen 80-84 år (6). Smertene påvirker hverdagsliv og sosiale funksjoner $(7,8)$ og kan være vanskelig å behandle (9). Det er tvil om hvorvidt antiviral behandling av det akutte utslettet reduserer risikoen (10).

Herpes zoster ophthalmicus er en akutt tilstand med risiko for synstap, og henvisning til oftalmolog og rask oppstart av antiviral behandling er nødvendig (11). Sjeldne komplikasjoner er Ramsey-Hunts syndrom og Bells parese, og økt risiko for apopleksi etter helvetesild er vist $(12,13)$.

\section{Forebyggende vaksine}

Én zostervirusvaksine er godkjent til forebygging av herpes zoster og postherpetisk nevralgi hos personer over 50 år i Norge. Flere kliniske studier har vist at vaksinen har effekt - og at den er trygg.

I en randomisert, placebokontrollert studie med 38546 deltakere over 60 år, med en median oppfølgingstid på tre år, fant man en relativ reduksjon i herpes zoster-insidens på $51,3 \%$ hos vaksinerte $(95 \% \mathrm{KI} 44,2-57,6)$ (14). Effekten var større hos dem som på vaksineringstidspunktet var under 70 år enn hos dem som var over 70 år (RR-reduksjon $64 \%$ versus $38 \%$ ). De som var vaksinert og som utviklet herpes zoster, hadde mindre risiko for postherpetisk nevralgi. Alvorlige bivirkninger ble rapportert med samme forekomst i vaksine- og placebogruppen. Injeksjonsassosierte bivirkninger etter vaksinering ble hyppigere rapportert hos dem som fikk vaksinen, men hoveddelen av disse var milde og forbigående (14).

I en retrospektiv kohortstudie der man sammenliknet 75761 vaksinerte over 60 år med 227283 ikke-vaksinerte, fant man en liknende effekt som i de kliniske studiene, uavhengig av underliggende kronisk sykdom og alder (15). I en kohortstudie med 766330 personer fant man en reduksjon $\mathrm{i}$ insidensen av herpes zoster fra 10 per 1000 personår hos ikke-vaksinerte til 5,4 per 1000 personår hos vaksinerte (16).

Varigheten av beskyttelsen er ukjent. I en oppfølgingsstudie fant man 7-10 år etter vaksinasjon en relativ reduksjon $\mathrm{i}$ insidensen av herpes zoster og postherpetisk

\section{«Flere kliniske studier}

\section{har vist at vaksinen}

$$
\begin{aligned}
& \text { har effekt - og at den } \\
& \text { er trygg» }
\end{aligned}
$$

nevralgi på henholdsvis $21 \%$ og $35 \%$, sammenliknet med en historisk kontrollgruppe. Gjennomsnittsalderen ved inklusjon var 74,5 år, og den avtakende effekten over tid skyldes muligvis aldring av gruppen (17). Risikoen for residiv av herpes zoster er lav, og den absolutte gevinst ved vaksinasjon av personer som tidligere har hatt sykdommen er derfor liten, men det er ikke større risiko for bivirkninger ved vaksinasjon av slike personer (18).

Med et økende antall eldre vil antallet tilfeller av herpes zoster og postherpetisk nevralgi trolig øke. En del tilfeller kan forebygges med vaksine, men kliniske studier har vist at effekten av vaksinen er avhengig av alderen på vaksinasjonstidspunktet og avtar over tid. I Norge er få vaksinert. De som ønsker å la seg vaksinere, må selv dekke utgiftene.

David Benee Olsen

dolsen@spmsd.com

David Benee Olsen (f. 1967) er lege og medisinsk sjef ved Sanofi Pasteur MSD.

Forfatter har fylt ut ICMJE-skjemaet og oppgir følgende interessekonflikter: Han er ansatt hos markedsføringsinnehaver av Zostavax.
Litteratur

1. Volpi A, Gross G, Hercogova J et al. Current management of herpes zoster: the European view. Am J Clin Dermatol 2005: 6: 317-25

2. Pinchinat $\mathrm{S}$, Cebrián-Cuenca AM, Bricout $\mathrm{H}$ et al. Similar herpes zoster incidence across Europe: results from a systematic literature review. BMC Infect Dis 2013: 13: 170.

3. Burke BL, Steele RW, Beard OW et al. Immune responses to varicella-zoster in the aged. Arch Intern Med 1982; 142: 291-3.

4. Weinberg A, Lazar AA, Zerbe GO et al. Influence of age and nature of primary infection on varicellazoster virus-specific cell-mediated immune responses. J Infect Dis 2010; 201: 1024-30.

5. Johnson RW, Rice AS. Clinical practice. Postherpetic neuralgia. N Engl J Med 2014; 371: 1526-33.

6. Gauthier A, Breuer J, Carrington D et al. Epidemiology and cost of herpes zoster and post-herpetic neuralgia in the United Kingdom. Epidemiol Infect 2009; 137: 38-47.

7. Scott FT, Johnson RW, Leedham-Green M et al. The burden of Herpes Zoster: a prospective population based study. Vaccine 2006; 24: 1308-14

8. Oster G, Harding G, Dukes E et al. Pain, medication use, and health-related quality of life in older persons with postherpetic neuralgia: results from a population-based survey. J Pain 2005; 6: 356-63.

9. Tontodonati M, Ursini T, Polilli E et al. Post-herpetic neuralgia. Int J Gen Med 2012; 5: 861-71.

10. Li Q, Chen N, Yang J et al. Antiviral treatment for preventing postherpetic neuralgia. Cochrane Database Syst Rev 2009; 2: CD006866.

11. Shaikh S, Ta CN. Evaluation and management of herpes zoster ophthalmicus. Am Fam Physician 2002: 66: 1723-30.

12. Kang J-H, Ho JD, Chen YH et al. Increased risk of stroke after a herpes zoster attack: a populationbased follow-up study. Stroke 2009; 40: 3443-8

13. Sreenivasan N, Basit S. Wohlfahrt J et al. The short- and long-term risk of stroke after herpes zoster - a nationwide population-based cohort study. PLoS ONE 2013; 8: e69156.

14. Oxman MN, Levin MJ, Johnson GR et al. A vaccine to prevent herpes zoster and postherpetic neuralgia in older adults. N Engl J Med 2005; 352: 2271-84.

15. Tseng HF, Smith N, Harpaz R et al. Herpes zoster vaccine in older adults and the risk of subsequen herpes zoster disease. JAMA 2011; 305: 160-6.

16. Langan SM, Smeeth L, Margolis DJ et al. Herpes zoster vaccine effectiveness against incident herpes zoster and post-herpetic neuralgia in an older US population. A cohort study. PLoS ONE 2013; 10: e1001420.

17. Morrison VA, Johnson GR, Schmader KE et al. Long-term persistence of zoster vaccine efficacy. Clin Infect Dis 2015; 60: 900-9

18. Tseng HF, Chi M, Smith N et al. Herpes zoster vaccine and the incidence of recurrent herpes zoster in an immunocompetent elderly population. $\mathrm{J}$ Infect Dis 2012; 206: 190-6.

Mottatt 3.3. 2015, første revisjon innsendt 20.3. 2015, godkjent 13.4. 2015. Redaktør: Lise Mørkved Helsingen.

Publisert først på nett. 